\title{
An Evaluation of the Effectiveness of Statistical Tools in Project Management Environments
}

Brian J. Galli, Hofstra University, USA

iD https://orcid.org/0000-0001-9392-244X

\begin{abstract}
Projects are very important to all organizations, as project managers view various issues in the organization from a higher perspective. The conclusions drawn from these projects determine the base on which various decisions affecting the organizations will be made. This paper introduces the statistical analysis tools used in various project environments to differentiate between the effective and ineffective tools of statistical analysis. Statistical analysis tools are useful in analyzing data collected for a study to be conducted on the same data. The literature review illustrates how statistical analysis tools have been effective and useful to researchers. Over time, more effective statistical tools will be invented that will improve the process of data analysis. The findings on different statistical analysis tools will also be highlighted. Thus, the discussions show the impact, applications, and lessons learned from the statistical analysis tools by the project managers and engineers. The study will also present the limitations, along with the conclusions and recommendations.
\end{abstract}

\section{KEYWORDS}

Descriptive Statistics, Hypothesis Testing, Project Management, Statistics

\section{INTRODUCTION}

Organizations undergo daily problems that need to be rectified. Project management mainly targets any future problems that the organization is likely to encounter, as well as the possible dangers that the problems may bring in the future (Ali \& Bhaskar, 2016; Besner \& Hobbs, 2012; Zwikael, \& Smyrk, 2012; Parker, Parsons, \& Isharyanto, 2015). Project managers are expected to plan the projects, supervise, and control all activities that determine the success of the projects. Since projects are normally exposed to great risks that threaten their success, the risk management tools are meant to ensure that the risks are reduced, controlled, or avoided (Carley \& Prietula, 2014; Ahern, Leavy, \& Byrne, 2014; Cova \& Salle, 2005; Galli, Kaviani, Bottani, \& Murino, 2017). A project management environment is where the project takes place, and it normally has a great impact on the project. Thus, the environment needs to have favorable conditions that will impact the project positively.

In the project environment, there is the interaction of various factors that include the physical factors, social factors, organizational factors, physiological factors, financial factors, cultural factors, 
operational factors, ecological factors, and economic factors. The effectiveness of all of these factors will estimate the success of the project. An unsuccessful project is usually an expense to the organization that causes great loss because the investment was expected to bring about profits. If a project is unsuccessful, then the investment becomes a waste, and no profit is expected. Thus, projects need to employ the use of statistical analysis tools to analyze the data and generate conclusions to make decisions. Several tools can be used in statistical analysis, such as activity diagrams, critical chain project management, critical path method, critical path drag, program evaluation and review technique, drag cost, etc.

\section{Research Statement}

Effective and ineffective statistical analysis tools in project management are aspects that largely determine the failure or success of an organization. This paper focuses on analyzing the two types of statistical analysis tools that are effective and ineffective in the environment of project management, which depends on how the tools are applied to the data and the environment in which the analysis is to be conducted.

Literature is available that stresses these variables, their concepts, and models as important factors in project management and performance, but a research gap has developed. Research does not address the part that these variables, their concepts, and models play in allowing a smooth progression in project management and performance. This study will attempt to fill this research void by focusing on assessing the elements and applications of these variables, their concepts, and models. The objective is to see overlaps and disparities to reveal any likenesses and differences. Afterwards, this study aims to prepare a universal framework, so as to amass the best practices and elements from the current model. This framework would apply to any form of project, operation, and performance. Also, answers are based on evidence for any primary questions from experts on these variables, their concepts, and models, such as how to best utilize them for project management and performance success. With this study, future researchers can use the findings as a platform on which to build a more detailed evaluation of this subject.

\section{Managerial Relevance}

Engineering managers must make vital decisions for project management and engineering. In the future, these decisions will grow in importance, and this study addresses future topics for the engineering management practitioner. This study also addresses how such future topics apply to engineering management, as well as reasons why the engineering manager must consider this in their operations, project management lifecycle, and project management settings. The implications of this study are addressed, and the findings are evaluated within various organizational levels: the corporate level, the managerial level, and the project team level. Lastly, the conclusions are useful to an engineering management practitioner for capitalizing on the variables, concepts, models, and their relationship from various project environment and operation levels.

\section{Originality}

Many companies conduct researches to try solving issues that arise in their respective organizations. Thus, it is vital for organizations to concentrate on selecting the most effective statistical analysis tools, as their results are always used for decision-making. The researchers must carefully select these analytical tools because an inappropriate tool can lead to poor analysis.

Furthermore, this research is meant to add to and expand on the literature about these variables, their concepts, and models, as well as the likenesses and differences of their assessment tools. Other studies that have examined the hypotheses in this paper added to the data within this study. This study first applies a design-science-investigate strategy, and it then supports a valuable growth reveal with reasonable and hypothetical application. Finally, this study produces an appropriate assessment model that encompasses elements of these variables, their concepts, and models. The evaluation 
instrument is addressed as a response to the examination question, and the development models are outlined. The study explains the approach to this outline and the consequences of the meeting, while the conclusion addresses preliminary discoveries, organizes investigative limitations, and provides plans for future studies.

With this study, there is a substantial contribution to literature on the application of these variables, their concepts, and models in project management and operations management. Thus, this study also contributes to the profession, as it shows the benefits of utilizing these variables, their concepts, and models and the detriments of not considering performance and sustainability. The examples are trueto-life, which shows the need to apply these theories into theory and practice.

\section{Organizational and Managerial Contribution and Relevance}

Since there is a knowledge gap in reference to these variables, concepts, and models, this study also aims to assess them to propose a unified framework. Future research could be disadvantaged with this knowledge gap, so this study will alleviate it. Additionally, various business subjects are addressed, so the results can enhance the subjects. By assessing how these variables, concepts, and models relate, future researchers can better recognize their advantages and disadvantages. For a practitioner, this study can help to know these variables, their relationship, and the implications in this study to develop better strategies.

\section{Contribution to the IE/EM Profession and Research Fields}

Industrial Engineering (IE) is a division of engineering that largely deals with designs and operations of industrial processes. For IE to run its operations successfully, it is bound to conducting sets of statistical analysis that help in making decisions for a sector to achieve its goals. Industrial engineering heavily relies on statistical analysis in its daily operations (Ali \& Bhaskar, 2016; Labedz \& Gray, 2013; Lee et al., 2013; Todorović et al., 2015). For example, a most commonly used procedure can deal with control statistics, sampling, and the determination of sampling portions that are required to give out results. On the other hand, engineering management can be defined as the application of management skills to the engineering practice (Carley \& Prietula, 2014; Winter et al., 2006a; Zhang et al., 2016; Xue, Baron, \& Esteban, 2016). Engineering management, as a profession, unites the problem-solving practice of engineering with the administrative, organizational, and planning practices of management to ensure that everything is in place for the daily performance of engineering enterprises. The effective and ineffective tools have been of great importance in Industrial Engineering and Engineering Management. Most of the projects in these two fields have been made successful because those responsible have carefully chosen and utilized the tools.

With this research, its information contributes to the IE research. This study can expedite the engineering work process, such as arranging and upholding the system with current technology, saving on time, money, materials, energy, work hours, machine time, and other resources that could inhibit productivity. Industrialists can also find useful information, which makes this study a contribution to the research field. Any reader can understand the vocabulary in this study, as it clearly depicts the effectiveness of these variables, their concepts, and models. Future readers can also find a clear theoretical framework with relevant information, which can help in gaining an edge over the competition.

\section{Paper Organization}

This paper is arranged into certain sections. In section two, there is a review of literature within these research fields. The research methodology is explained in section three. Also, section four features the findings from the study and analysis. The implications are outlined in section five for the practitioner, and there are ideas presented for future research, research limitations, and general conclusions. 


\section{LITERATURE REVIEW}

To fully review the effective and ineffective statistical tools in project management environments, one needs to know all of the statistical tools. The tools are the methods that are used in the analysis (Christensen et al., 2011; Parast, 2011; Papke-Shields \& Boyer-Wright, 2017; Loyd, 2016; Azar, 2012). Research shows that these methods have been used for quite a long time, whereby some have proven to be effective or ineffective. According to the researchers, effective tools should be the ones that meet the following factors:

i) Ones that bring or provide answers to scientific questions

ii) Ones that ease the reproduction of the analysis

iii) Ones that check assumptions of a researcher in analysis

iv) Tools that are simple

v) Tools that tend to highlight the quality of the data

vi) Tools that help in planning ahead

vii) Tools that provide assessment for uncertainty

viii) Tools that make statistical analysis appear to be more than sets of computations

From the above rules, one can easily identify a statistical tool that meets these requirements (Carley \& Prietula, 2014; Hoon Kwak, \& Dixon, 2008; Eskerod \& Blichfeldt, 2005; Brown \& Eisenhardt, 1995). However, most of the statistical tools have been developed with time and continue to be developed to ensure that they provide the required outcomes (Christensen et al., 2011; Galli, 2018a; Galli, 2018b; Galli, 2018c).

\section{RESEARCH METHODOLOGY}

\section{Literature Review Research Approach}

For the literature review, there are two steps: first, the search for relevant information (inputs from keywords) and second, a more structured review process that involved databases and search strong. The tables of contents for two journals were searched through, as they also applied.

\section{Part 1: Explorative and Unstructured Literature Review}

This study aimed to reconsider some keywords, so publications that reflected the keywords were assessed. This resulted in 31 journal articles and 7 books. The keywords were also evaluated from the total 38 publications, as these would be used as search terms in the structured review.

\section{Part 2: Structured Literature Review}

A structured and systematic approach was then used to conduct reviews that were featured in other literature. There are four phases to this section, as the first phase dealt with preparing and scoping. The second phase dealt with preparing for the review. Phase three was the searching, evaluating, and selecting of literature, while phase four featured assessing all selected literature.

In phase (1), the review scope highlighted project-relevant research on marketing and strategic planning as being vital to the studies. It was expected that the search would lead to a sufficient amount of evidence and data to contribute to the study.

Phase (2) entailed other concepts being attached to the keywords for more information. Other concepts were comprised of the keywords, their relationship, and their interaction. Certain concepts were too vague, such as success, evaluation, and impact; these concepts did not result in practical and focused results. 
Phase (3) was the successful compilation of results. Many databases were used, such as ProQuest, Business Source Complete, Elsevier, EBSCO, and ScienceDirect, which resulted in 15 conference papers and 25 results. This resulted in a total of 40 results from conference and journal papers.

The end of the search involved a search through the tables of contents for tier 1 and tier 2 journals, which were both academic and practitioner-based. Any relevant article was found that may not have matched the keywords, and articles that were chosen would become premier specialty journals for the keywords. Figure 1 depicts the search and selection, as well as its three streams: the explorative and unstructured search, the structured search with search strings, and examining the tables of contents.

Utilizing the three streams limited the results to 42 publications in the analysis. The selection process yielded between 24 and 18 results, as it focused on academic journal articles, literature reviews, conference papers and proceedings, and books. Triangulation methods were used, and the first selection aimed to determine if the resulting publications connected to the keywords and project research. The evaluation involved inclusion and exclusion criteria that highlighted the abstract, as some publications featured the introduction or the entire paper.

For phase (4), the information was organized into an inductive and deductive analysis that was documented with a software package, as well. The deductive analysis entailed documenting the university and country from the authors, along with suggested categories. Research genres were indicated as the following: empirical research, theory development, research essays and literature reviews, or "other". Also, deductive coding was applied with evidence that the publications utilized theoretical frameworks, such as with a research-based view and contingency theory. It was also indicated if the publication did or did not feature a model.

A grounded theory approach was then used throughout the inductive analysis for coding some publications with open and selective codes. Most of the selected literature was from the annual average number of citations, which provided balance for the older publications. Relevant literature reviews were added, as well as current publications that provided substantial contributions to the keywords research.

Phase (4) illustrates that key themes resulted from assessing the list of open codes, so as to gather them for axial and selective codes. The literature review process began with the first two phases in April 2018 and August 2018, while the final evaluation for pertinent materials and their relationship was also performed within this time period.

Gathering these papers illustrates that key themes are shared between the variables and concepts from descriptive and trait perspectives. Also, statistical analysis and the investigation of other variables or factors gave weight to this study's research conclusions. The following section features Table 1, which shows the 42 studies and the key themes.

Evaluating the 42 studies resulted in finding that the literature assessed the keywords with statistical methods from relational and causal perspectives, which gave weight to the research conclusions. In Table 2, the statistical methods are summarized that were used for the 42 studies, while Table 3 summarizes the number of factors or variables that were assessed in the journals.

The following section will feature the findings for these research methods, which are based on the themes/topics from later sections.

\section{FINDINGS}

In every project, there must be a collection of data that will be analyzed to draw conclusions from the analysis (Christensen et al., 2011; David, David, \& David, 2017; Galli \& Hernandez-Lopez, 2018; Hartono, FN Wijaya, \& M. Arini, 2014). In the past, collecting data was difficult because data was not readily available. Individuals had to physically go to the venues where the data was to be collected (Marchewka, 2014; Medina \& Medina, 2015; Sharon, Weck, \& Dori, 2013; Svejvig \& Andersen, 2015). Furthermore, time-consuming methods, such as interviewing or observing, had to be used to obtain raw data. Due to advancement in technology, data collection has become easier because 
Figure 1. Research approach for literature review

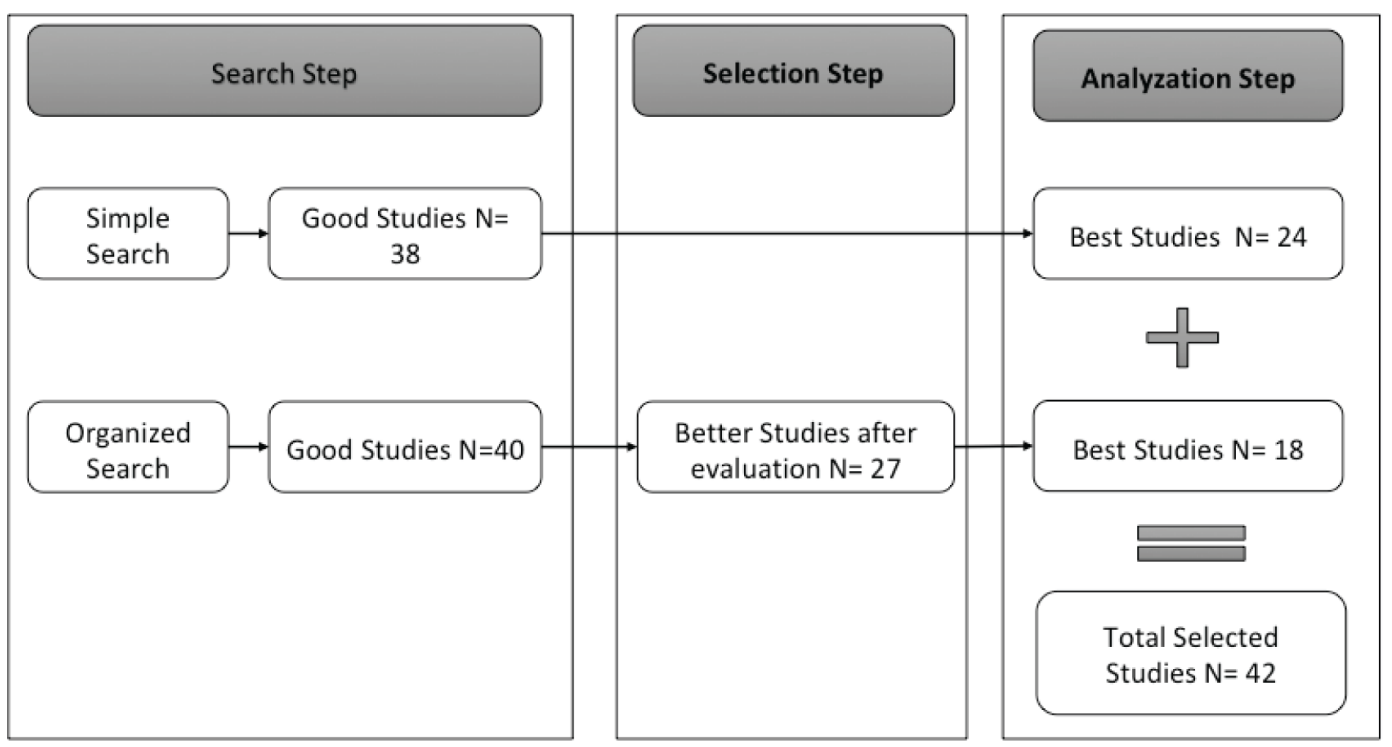

secondary data sources are available on the internet. Also, the internet contains all information and data required in a project (Ali \& Bhaskar, 2016; Von Thiele Schwarz, 2017; Yun et al., 2016; Xiong et al., 2017; Zelinka \& Amadei, 2019). Additionally, private and public organizations publish their monthly and annual reports, which are accessible to the public. In the project, organizations tend to use large volumes of data that need advanced statistical analysis tools. For statistical tools to be effective, there are several things that a researcher needs to consider. First of all, it is important to note the objectives of the study to use the appropriate statistical tool correctly. If one of the objectives is to obtain the average of the data, then the mean will be used (Harris \& McCaffer, 2013; Al-Kadeem, et al., 2017a; Andersen, 2014; Arumugam, 2016; Badi \& Pryke, 2016).

\section{Descriptive Statistics}

Descriptive statistics is one of the statistical analysis tools that analyze the raw data to present it in a meaningful way for project managers to interpret more easily. The descriptive statistics contain the measures of central tendency: the mean, mode, and median measures of spread that is the standard deviation and variance, the minimum value, the maximum value, and the range between them. The mode is significant to the project managers because it enables them to determine the most sampled data value. For example, if a project required data on the incomes of people in a given neighborhood per month and the mode value is $\$ 1000$, then the project managers will automatically conclude that most individuals in the neighborhood receive a monthly income of $\$ 1000$. The median is the middle data value when the data set is arranged in ascending order (Harris \& McCaffer, 2013; Burnes, 2014; Detert, 2000; Nikabadi \& Hakaki, 2018; J. W., 2018). If some values in the data set are odd numbers, then the middle value is one, but if the number of values in the data set is an even number, then the middle values will be two. Therefore, the median is the average of those two values. The median is supposed to estimate the average of the data set to the project managers, but in a case where the data set has outliers, this is not applicable (Marchewka, 2014; Easton \& Rosenzweig, 2012; Galli and Kaviani, 2018; Nabavi \& Balochian, 2018). The mean gives the average value of the given dataset, but there are different types of mean, and each type is used in a different context. Understanding the types of mean is vital in any data analysis process to obtain an appropriate value that will give the right information (Vergura et al., 2009). 
Table 1. Identified studies from research approach by theme

\begin{tabular}{|c|c|}
\hline Theme \#1 & Theme \#2 \\
\hline $\begin{array}{l}\text { Ahern, Leavy, \& Byrne, (2014) } \\
\text { Andersen, (2014) } \\
\text { Arumugam, (2016) } \\
\text { Cova \& Salle (2005) } \\
\text { David, David, \& David, (2017) } \\
\text { Eskerod \& Blichfeldt, (2005) } \\
\text { Galli \& Kaviani, (2018) } \\
\text { Galli et al., (2017) } \\
\text { George, Haas, \& Pentland, (2014) } \\
\text { Hartono, FN Wijaya, \& Arini, (2014) } \\
\text { Healey, (2014) } \\
\text { Manly \& Alberto, (2016) } \\
\text { Schwedes, Riedel, \& Dziekan, (2017) } \\
\text { Xue, Baron, \& Esteban, (2016) } \\
\text { Xue, Baron, \& Esteban, (2017) } \\
\text { Zelinka \& Amadei, (2019) }\end{array}$ & $\begin{array}{l}\text { Ali \& Bhaskar, (2016) } \\
\text { Al-Kadeem et al., (2017a) } \\
\text { Azar, (2012) } \\
\text { Badi \& Pryke, (2016) } \\
\text { Carley \& Prietula, (2014) } \\
\text { Gafi \& Javadian, (2018) } \\
\text { Gimenez-Espin, (2013) } \\
\text { Kwak, \& Dixon, (2008) } \\
\text { Medina \& Medina, (2015) } \\
\text { Milner, (2016) } \\
\text { Nikabadi \& Hakaki, (2018) } \\
\text { Parast, (2011) } \\
\text { Parker, Parsons, \& Isharyanto, (2015) } \\
\text { Sharon, Weck, \& Dori, (2013) } \\
\text { Shenhar \& Levy, (2007) } \\
\text { Sutherland, (2004) } \\
\text { Yun et al. (2016) }\end{array}$ \\
\hline Theme \#3 & Theme \#4 \\
\hline $\begin{array}{l}\text { Christensen et al., (2011) } \\
\text { Detert, (2000) } \\
\text { Easton \& Rosenzweig, (2012) } \\
\text { Galli, \& Hernandez-Lopez, (2018) } \\
\text { Galli, (2018c) } \\
\text { Ghosh, Ramteke, \& Srinivasan, (2014) } \\
\text { Gholizad et al., (2017) } \\
\text { J. W. (2018) } \\
\text { Kerzner \& Kerzner, (2017) } \\
\text { Labedz \& Gray, (2013) } \\
\text { Lee et al. (2013) } \\
\text { Marchewka, (2014) } \\
\text { Modarres, (2016) } \\
\text { Nabavi \& Balochian, (2018) } \\
\text { Svejvig \& Andersen, (2015) } \\
\text { Todorović et al. (2015) } \\
\text { Usman Tariq, (2013) } \\
\text { Vergura et al., (2009) } \\
\text { Von Thiele Schwarz, (2017) } \\
\text { Zikmund et al., (2013) } \\
\text { Zwikael \& Smyrk, (2012) }\end{array}$ & $\begin{array}{l}\text { Aslani, Akbari, \& Tabasi, (2018) } \\
\text { Besner \& Hobbs, (2012) } \\
\text { Brown \& Eisenhardt, (1995) } \\
\text { Burnes, (2014) } \\
\text { Galli, (2018a) } \\
\text { Galli, (2018b) } \\
\text { Harris \& McCaffer, (2013) } \\
\text { Hazır, (2015) } \\
\text { Hox, Moerbeek, \& Van de Schoot, (2017) } \\
\text { Loyd, (2016) } \\
\text { Marcelino-Sádaba et al., (2014) } \\
\text { Mertler \& Reinhart, (2016) } \\
\text { Nagel, (2015) } \\
\text { Ott \& Longnecker, (2015) } \\
\text { Papke-Shields, \& Boyer-Wright, (2017) } \\
\text { Simundic, (2018) } \\
\text { Velte \& Stawinoga, (2017) } \\
\text { Williams, (2018) } \\
\text { Winter et al. (2006a) } \\
\text { Xiong et al. (2017) } \\
\text { Zhang et al., (2016) }\end{array}$ \\
\hline
\end{tabular}

Arithmetic mean is the most basic type of mean that gives the average of the total number of values collected as data (Vergura et al., 2009; Gimenez-Espin, 2013; Marcelino-Sádaba et al., 2014). Arithmetic mean is given by summing together all values and dividing them by the total number of values. Also, it is used in analyzing data that has no outliers that are the data set, and it has no extreme values. Furthermore, it may be useful to meteorologists in calculating the arithmetic means of the temperature of particular regions where the range of temperatures is close, as they carry on with their projects on weather conditions. Most importantly, arithmetic mean is easy to calculate and also easy to understand (George, Haas, \& Pentland, 2014; Milner, 2016; Sutherland, 2004). Since it is based on observation, it is a good representation of the whole data set, but it is not applicable where the data set is a continuous interval with an open end.

Let $\mathrm{x}_{1}, \mathrm{x}_{2}, \mathrm{x}_{3}, \ldots \mathrm{x}_{\mathrm{n}}$ be $n$ values: 
Table 2. Systematic analysis results by statistical analysis method

\begin{tabular}{|c|c|c|}
\hline Statistical Method & Number of Articles (Frequency) & Author(s) \\
\hline Regression & $\begin{array}{l}19 \\
\text { ( } 25.00 \% \text { of total articles) }\end{array}$ & $\begin{array}{l}\text { Ali \& Bhaskar, (2016) } \\
\text { Azar, (2012) } \\
\text { Carley \& Prietula, (2014) } \\
\text { Cova \& Salle, (2005) } \\
\text { David, David, \& David, (2017) } \\
\text { Detert, (2000) } \\
\text { Easton \& Rosenzweig, (2012) } \\
\text { Galli et al., (2017) } \\
\text { Gafi \& Javadian, (2018) } \\
\text { Gholizad et al., (2017) } \\
\text { Gimenez-Espin, (2013) } \\
\text { Harris \& McCaffer, (2013) } \\
\text { Loyd, (2016) } \\
\text { Nabavi \& Balochian, (2018) } \\
\text { Nikabadi \& Hakaki, (2018) } \\
\text { Ott \& Longnecker, (2015) } \\
\text { Sutherland (2004) } \\
\text { Xue, Baron, \& Esteban, (2017) } \\
\text { Zwikael \& Smyrk, (2012) }\end{array}$ \\
\hline ANOVA & $\begin{array}{l}15 \\
(19.74 \% \text { of total articles) }\end{array}$ & $\begin{array}{l}\text { Ahern, Leavy, \& Byrne, (2014) } \\
\text { Aslani, Akbari, \& Tabasi, (2018) } \\
\text { Brown, \& Eisenhardt, (1995) } \\
\text { Christensen et al., (2011) } \\
\text { Galli, (2018b) } \\
\text { Galli, (2018c) } \\
\text { Ghosh, Ramteke, \& Srinivasan, (2014) } \\
\text { Healey, (2014) } \\
\text { Manly \& Alberto, (2016) } \\
\text { Mertler \& Reinhart, (2016) } \\
\text { Nagel, (2015) } \\
\text { Papke-Shields \& Boyer-Wright, (2017) } \\
\text { Xiong et al., (2017) } \\
\text { Yun et al. (2016) } \\
\text { Zelinka \& Amadei, (2019) }\end{array}$ \\
\hline Q-Test & $\begin{array}{l}15 \\
\text { (19.74\% of total articles) }\end{array}$ & $\begin{array}{l}\text { Arumugam, (2016) } \\
\text { Badi \& Pryke, (2016) } \\
\text { George, Haas, \& Pentland, (2014) } \\
\text { Hazır, (2015) } \\
\text { Hoon Kwak, \& Dixon, (2008) } \\
\text { J. W. (2018) } \\
\text { Labedz \& Gray, (2013) } \\
\text { Modarres, (2016) } \\
\text { Parker, Parsons, \& Isharyanto, (2015) } \\
\text { Schwedes, Riedel, \& Dziekan, (2017) } \\
\text { Usman Tariq, (2013) } \\
\text { Velte \& Stawinoga, (2017) } \\
\text { Von Thiele Schwarz, (2017) } \\
\text { Williams, (2018) } \\
\text { Zikmund et al., (2013) }\end{array}$ \\
\hline t-Test & $\begin{array}{l}13 \\
\text { (17.11\% of total articles) }\end{array}$ & $\begin{array}{l}\text { Andersen, (2014) } \\
\text { Azar, (2012) } \\
\text { Besner \& Hobbs, (2012) } \\
\text { Burnes, (2014) } \\
\text { Eskerod \& Blichfeldt, (2005) } \\
\text { Galli, (2018a) } \\
\text { Hox, Moerbeek, \& Van de Schoot, (2017) } \\
\text { Winter et al., (2006a) } \\
\text { Hartono, FN Wijaya, \& Arini, (2014) } \\
\text { Lee et al., (2013) } \\
\text { Sharon, Weck, \& Dori, (2013) } \\
\text { Shenhar \& Levy, (2007) } \\
\text { Zhang et al. (2016) }\end{array}$ \\
\hline
\end{tabular}




\begin{tabular}{|l|l|l|}
\hline \multicolumn{1}{|c|}{ Statistical Method } & \multicolumn{1}{|c|}{ Number of Articles (Frequency) } & \multicolumn{1}{c|}{ Author(s) } \\
\hline & & Al-Kadeem et al. (2017a) \\
& & Galli \& Kaviani, (2018). \\
Galli \& Hernandez-Lopez, (2018) & Kerzner \& Kerzner, (2017) \\
& & Marcelino-Sádaba et al., (2014) \\
Marchewka, (2014) \\
Chi-Square Test & & Medina \& Medina, (2015) \\
& 14 & Milner, (2016) \\
& Parast, (2011) \\
& Simundic, (2018) \\
& & Svejvig \& Andersen, (2015) \\
& & Todorović et al., (2015) \\
& & Vergura et al., (2009) \\
& Xue, Baron, \& Esteban, (2016) \\
\hline
\end{tabular}

Then Arithmetic Mean $=\frac{x_{1}+x_{2}+x_{3}+\ldots+x_{n}}{n}\left(A . M .=\frac{\text { Sum of values }}{\text { Countof Values }}\right)$

$=\frac{\sum_{i-1}^{n} x_{i}}{n}\left(\sum_{i=1}^{n} x_{i} i s x_{1},+x_{2}+x_{3}+\ldots+x_{n}\right.$
$=\frac{1}{n} \times \sum_{i=1}^{n} x_{i}$ Since $\frac{a}{b}$ canbewritten as $\frac{1}{b} \times a$

$\mathrm{X}_{\mathrm{i}}=$ the values in the data set, $\mathrm{n}=$ total number of the data values

The second type of mean that is also a statistical tool is the geometric mean, which is calculated by multiplying all figures in the data set and getting the $n t h$ root where $n$ is the total number of figures in the dataset. The geometric mean is different from the arithmetic mean because it takes care of outliers. During the analysis, the geometric mean only takes care of the values in a close range and focuses less on the outliers. Geometric mean can be useful to the biologists having a project that requires them to determine the size of the populations of different bacteria (Ghosh, Ramteke, \& Srinivasan, 2014; Nagel, 2015; Schwedes, Riedel, \& Dziekan, 2017; Aslani, Akbari, \& Tabasi, 2018). It can also be useful to economists having a project that requires them to determine the distribution of the incomes in a particular neighborhood. The geometric mean is useful in financial institutions for calculating the growth rates and returns on different portfolios and applying the findings in various projects. The geometric mean is not easy to calculate and understand like the arithmetic mean (George, Haas, \& Pentland, 2014; Usman Tariq, 2013; Gafi \& Javadian, 2018). It also does not take care of negative values, so if one of the values in a given data set is negative, then the geometric mean may not be applicable. The formula of geometric mean is given by:

$$
\left(\prod_{i=1}^{n} a_{i}\right)^{1 / n}=\sqrt[n]{a_{1} a_{2} a_{3}, \ldots a_{n}}
$$

$\mathrm{a}_{\mathrm{i}}=$ the values in the data set, $\mathrm{n}=$ total number of the data values

The third type of mean, which is also a commonly used statistical tool, is the weighted mean. In the weighted mean, all of the values in the data set do not give an equal contribution to the final total figure (Hazır, 2015; Shenhar \& Levy, 2007; Gholizad, Ahmadi, Hassannayebi, Memarpour, 
Table 3. Systematic analysis results by number of variables studied

\begin{tabular}{|c|c|c|}
\hline No. Factors Studied & Number of Articles (Frequency) & Author(s) \\
\hline 1 & $\begin{array}{l}17 \\
(22.37 \% \text { of total articles) }\end{array}$ & $\begin{array}{l}\text { Andersen, (2014) } \\
\text { Aslani, Akbari, \& Tabasi, (2018) } \\
\text { Besner \& Hobbs, (2012) } \\
\text { Carley \& Prietula, (2014) } \\
\text { David, David, \& David, (2017) } \\
\text { Galli, (2018b) } \\
\text { J. W. (2018) } \\
\text { Lee et al., (2013) } \\
\text { Medina \& Medina, (2015) } \\
\text { Nagel, (2015) } \\
\text { Nikabadi \& Hakaki, (2018) } \\
\text { Ott \& Longnecker, (2015) } \\
\text { Papke-Shields \& Boyer-Wright, (2017) } \\
\text { Sutherland, (2004) } \\
\text { Von Thiele Schwarz, (2017) } \\
\text { Yun et al., (2016) } \\
\text { Zelinka \& Amadei, (2019) }\end{array}$ \\
\hline 2 & $\begin{array}{l}11 \\
(14.47 \% \text { of total articles) }\end{array}$ & $\begin{array}{l}\text { Al-Kadeem et al. (2017a) } \\
\text { Brown, \& Eisenhardt, (1995) } \\
\text { Galli \& Hernandez-Lopez, (2018) } \\
\text { Gafi \& Javadian, (2018) } \\
\text { Gholizad et al., (2017) } \\
\text { Harris \& McCaffer, (2013) } \\
\text { Healey, (2014) } \\
\text { Manly \& Alberto, (2016) } \\
\text { Marchewka, (2014) } \\
\text { Shenhar, \& Levy, (2007) } \\
\text { Xue, Baron, \& Esteban, (2016) }\end{array}$ \\
\hline 3 & $\begin{array}{l}13 \\
\text { ( } 17.11 \% \text { of total articles) }\end{array}$ & $\begin{array}{l}\text { Arumugam, (2016) } \\
\text { Badi \& Pryke, (2016) } \\
\text { Eskerod, \& Blichfeldt, (2005) } \\
\text { Galli et al., (2017) } \\
\text { Gimenez-Espin, (2013) } \\
\text { Loyd, (2016) } \\
\text { Marcelino-Sádaba et al., (2014) } \\
\text { Mertler \& Reinhart, (2016) } \\
\text { Modarres, (2016) } \\
\text { Svejvig \& Andersen, (2015) } \\
\text { Usman Tariq, (2013) } \\
\text { Winter et al., (2006a) } \\
\text { Zhang et al., (2016) }\end{array}$ \\
\hline 4 & $\begin{array}{l}10 \\
(13.16 \% \text { of total articles) }\end{array}$ & $\begin{array}{l}\text { Ahern, Leavy, \& Byrne, (2014) } \\
\text { Detert, (2000) } \\
\text { Easton \& Rosenzweig, (2012) } \\
\text { Galli, (2018a) } \\
\text { Hoon Kwak, \& Dixon, (2008) } \\
\text { Kerzner \& Kerzner, (2017) } \\
\text { Labedz \& Gray, (2013) } \\
\text { Parast, (2011) } \\
\text { Todorović et al. (2015) } \\
\text { Zwikael \& Smyrk, (2012) }\end{array}$ \\
\hline 5 & $\begin{array}{l}12 \\
(15.79 \% \text { of total articles) }\end{array}$ & $\begin{array}{l}\text { Ali \& Bhaskar, (2016) } \\
\text { Azar, (2012) } \\
\text { Burnes, (2014) } \\
\text { Cova \& Salle, (2005) } \\
\text { Galli, (2018c) } \\
\text { George, Haas, \& Pentland, (2014) } \\
\text { Hazır, (2015) } \\
\text { Hox et al., (2017). } \\
\text { Sharon, Weck \& Dori, (2013) } \\
\text { Velte \& Stawinoga, (2017) } \\
\text { Xue, Baron, \& Esteban, (2017) } \\
\text { Zikmund et al., (2013) }\end{array}$ \\
\hline
\end{tabular}




\begin{tabular}{|l|l|l|}
\hline No. Factors Studied & \multicolumn{1}{|c|}{ Number of Articles (Frequency) } & \multicolumn{1}{c|}{ Author(s) } \\
\hline \multirow{6}{*}{} & & Christensen et al., (2011) \\
& & Galli \& Kaviani, (2018) \\
& & Ghosh, Ramteke, \& Srinivasan, (2014) \\
& & Hartono, FN Wijaya, \& Arini, (2014) \\
& 12 & Milner, (2016) \\
& $(15.79 \%$ of total articles) & Nabavi \& Balochian, (2018) \\
& & Parker, Parsons, \& Isharyanto, (2015) \\
& & Schwedes, Riedel, \& Dziekan, (2017) \\
& & Simundic, (2018) \\
& & Vergura et al., (2009) \\
& Williams, (2018) \\
& & Xiong et al., (2017) \\
\hline
\end{tabular}

\& Shakibayifar, 2017). The weighted mean is used mostly in cases where some values in the data set have more worth than others. This is a statistical analysis tool that may be used in analyzing performance in a learning institution where the final test bears more weight than the assessment tests. When tutors have a project of studying the average performance of their students throughout the term, they will have more weight in the final exam than on the assessment tests. The formula for the weighted mean is given by:

$$
\bar{x}_{w}=\frac{\sum_{\mathrm{i}=1}^{n}\left(w_{i} x_{i}\right)}{\sum_{\mathbf{i}=1}^{n}\left(w_{i}\right)}
$$

whereas:

- $\bar{x}_{w}$ is the weighted mean variable

- $w_{\mathrm{i}}$ is the allocated weighted value

- $x_{\mathfrak{i}}$ is the observed values

Finally, harmonic mean is, in most cases, used in analyzing data that concerns average speed. It is rarely used because of the limited data sets of speed values. Also, it is calculated by dividing the total number of values into the data set by the sum of the reciprocal of all values in the dataset. The formula is as shown below:

$$
H=\frac{n}{\frac{1}{x_{1}}+\frac{1}{x_{2}}+\ldots+\frac{1}{x_{n}}}=\frac{n}{\sum_{i=1}^{n} \frac{1}{x_{i}}}=\left(\frac{\sum_{i=1}^{n} x_{i}^{-1}}{n}\right)^{-1}
$$

$\mathrm{X}_{\mathrm{i}}=$ the values in the data set, $\mathrm{n}=$ total number of the data values

From these statistical tools that analyze the average of a data set, it is important to analyze the set of data before deciding on which statistical analysis (average) tool to use. Also, it is important to scrutinize the range of the data values and if there are any outliers. One should identify the type of dataset that is being analyzed for the project. For example, data on speed will use the harmonic mean (Hazır, 2015). 
The measure of dispersion or spread that is the variance and standard deviation measure show that the dataset is from the mean. If the value of the standard deviation is small, then the project managers will understand that the data values in the data set are close to the mean and vice versa. Standard deviation is calculated as follows:

$$
\sqrt{\frac{\sum(x-\bar{x})^{2}}{(n-1)}}
$$

where:

$\mathrm{x}=$ each score

$\bar{x}=$ the mean or average

$\mathrm{n}=$ the number of values

$\Sigma=$ means we sum across the values

The variance is also used to measure the extent to which the data is distributed from the mean. It is the square of standard deviation. Its formula is given by:

$$
\begin{aligned}
\sigma^{2} & =\sum\left(x_{i}-\bar{x}\right)^{2} / N \\
\sigma^{2} & =\text { variance } \\
x_{i} & =\text { the value of the ith element } \\
\bar{x} & =\text { the mean of } \mathrm{x} \\
\mathrm{N} & =\text { the number of elements }
\end{aligned}
$$

\section{Data Distributions}

Data distributions are also statistical analysis tools. In project management, before employing the use of statistical analysis tools, an individual needs to understand the distribution of the data collected (Healey, 2014). There are various types of distributions, such as normal distribution, binomial distribution, negative binomial, Poisson distribution, uniform distribution, exponential distribution, and Bernoulli distribution, among many others (Kerzner \& Kerzner, 2017). To determine the data distribution, the project managers are required to observe the data and to discover the available parameters. For example, for a data set to be a binomial distribution, probability and the total number of the data values must be known (Ghosh et al., 2014).

\section{Hypothesis Testing}

A hypothesis is a statement in a project that presents a given fact that is yet to be fully investigated. Hypothesis testing helps in proving the validity of the hypothesis statement, while the hypothesis test helps in determining the truth and significance of the hypothesis statement. The statement whose significance is being tested is referred to as the null hypothesis (Kerzner \& Kerzner, 2017; Xue, Baron, \& Esteban, 2017). Also, the calculation of the p-value is commonly referred to as the probability value. When the p-value is small that is $\leq 0.05$, then it implies that the evidence is too weak, so the null hypothesis is rejected. If the p-value is large or $>0.05$, then the null hypothesis is not rejected, since the evidence supporting the hypothesis statement is too strong (Healey, 2014). 


\section{Parametric and Non-Parametric Tests}

Parametric and non-parametric tests are also used as statistical analysis tools for analyzing data. However, before using either of these tools, it is important to study the data that is to be analyzed carefully.

Parametric tests are mostly used in analyzing normal distributions. Most data sets are normally distributed to employ the use of parametric tests. Parametric tests assume that the mean of the collected sample is normally distributed and that the variances of the samples and those of the populations from which the samples were collected are equal. The most common parametric test is the ANOVA, which is also known as the analysis of variance, the student t-test, and the repeated measures. However, parametric tests can give erroneous results (Ghosh et al., 2014).

1. Analysis Of Variance (ANOVA): The above parametric test is used to any difference, which is significant between the means of two or more given groups. In ANOVA, two variances are studied: the variance between the groups and the variance within each group. The second variance, the within-group variance, which is also known as the error variance, is the variation which cannot be incapacitated in the study. The variances in parametric tests are compared using the F-test. The F statistic is given by:

$$
F=\frac{M S_{b}}{M S_{w}}
$$

2. The Student T-Test: This test is used to determine the null hypothesis that the means of two different groups are equal. It is used in determining if the mean of a sample is equal to the mean of the population. It can also test if two different samples collected from one population have equal means. The formula for the t-test is:

$$
t=\frac{d}{S E_{d}}
$$

3. Repeated Measures Analysis of Variance: This is a test that is used to measure if the mean of three or more groups is equal. In repeated measures ANOVA, the measures of the samples are carried out in different conditions and at different times. The dependent variable is measured repeatedly (Simundic, 2018).

Meanwhile, non-parametric tests are applicable where the data being analyzed is not normally distributed. They are also called distribution-free test. Unlike parametric tests, non-parametric tests cannot give results that are erroneous. In most cases, non-parametric tests are usually used in situations that do not require normality assumptions (Simundic, 2018).

\section{DISCUSSION}

\section{Implications of Statistical Tools in Project Management Environment to Engineering Managers and Project Managers}

Effective and ineffective statistical tools are important in many fields of projects. At the same time, engineering managers and project managers widely rely on these tools to analyze robust data. Thus, both fields require a vast experience and use of data. Data cannot be just collected and used; it needs 
a keen analysis to help in generating concrete solutions for the projected problems. Thus, engineering managers and project managers get involved in the use of statistical tools in a project management environment (Hox, Moerbeek, \& Van de Schoot, 2017).

\section{Organizational Implications}

As seen in the research on the acquired skill and management strategies, these variables, their concepts, and models are effective tools for business projects and project management; they lead to team skills that can help to better fulfill company goals. Thus, technology is not as vital to business projects and project management. In the results, it is also illustrated that strategic planning is essential because a top-down and bottom-up leadership approach is important to project management, operations management, and process improvement. Also, these variables, concepts, and models are crucial to leadership styles and tools, as businesses require the proper skills to manage their project management and performance.

Leadership must have a focus on more aspects to a business than just the bottom line. This study reveals that a lack of leadership has led to issues in project management and operational performance. The bottom line approach only solves problems temporarily, but in the long run, leadership must manage multiple elements. For example, operations, project management, financials, performance, strategy, and human resources are all important to a business. By addressing the importance of these aspects to business, leadership can find greater success in the present and future.

\section{Implications to the Engineering Managers}

Statistics are very important tools in the world of engineering because engineers need to analyze data in their daily operations. An engineering manager is someone who organizes, directs and plans to engineer to ensure that company's objectives are met for either design, improvement of products, development of products, and design by undertaking several responsibilities within an organization (Manly \& Alberto, 2016). The field of statistics helps the engineering manager in the collection of data, presentation of data, and in the usage of data in helping an organization to make relevant decisions that affect it and in designing products and processes (Hox, Moerbeek, \& Van de Schoot, 2017). Most aspects of the practice of engineering involve the use of data, so it is important for an engineering manager to know statistics. To be specific, statistics can be of great help in the designation of new products, improvement of existing designs, and improvement of the process of production.

In this study, there are some implications. Firstly, the results evaluate the variables, concepts, models, and their relationship by taking a novel approach to fill a research void. Furthermore, this study evaluates how the variables affect each other and other factors. Secondly, projects and performances of organizations can use this study as an outline. Mentoring and managerial constructs can be created from learning about the relationship between these variables, so teams and businesses can identify their limitations in project and organizational performance. Lastly, this study offers guidance on creating better training constructs for project and organizational performance and effectiveness. Most of all, project teams, project leadership, and organizational leadership can be trained on measuring a team, project, or business' performance against standard and industry-accepted models. Thus, performance and effectiveness will improve, as teams and leaders can discover how teams and projects affect performance and reliability.

\section{Engineering Method and Statistical Thinking}

The engineering method has several steps that help in solving problems and in generating concrete solutions to the problems. Below is a diagram (Figure 2) that shows the process followed by engineering managers, which is referred to as the engineering method.

From the above diagram, the engineering managers need to ensure that they state a problem, get facts about the problem, defend viewpoints about the problem, formulate opinions about the problem, and qualify recommendations (Manly \& Alberto, 2016). Statistical tools help an engineering manager 


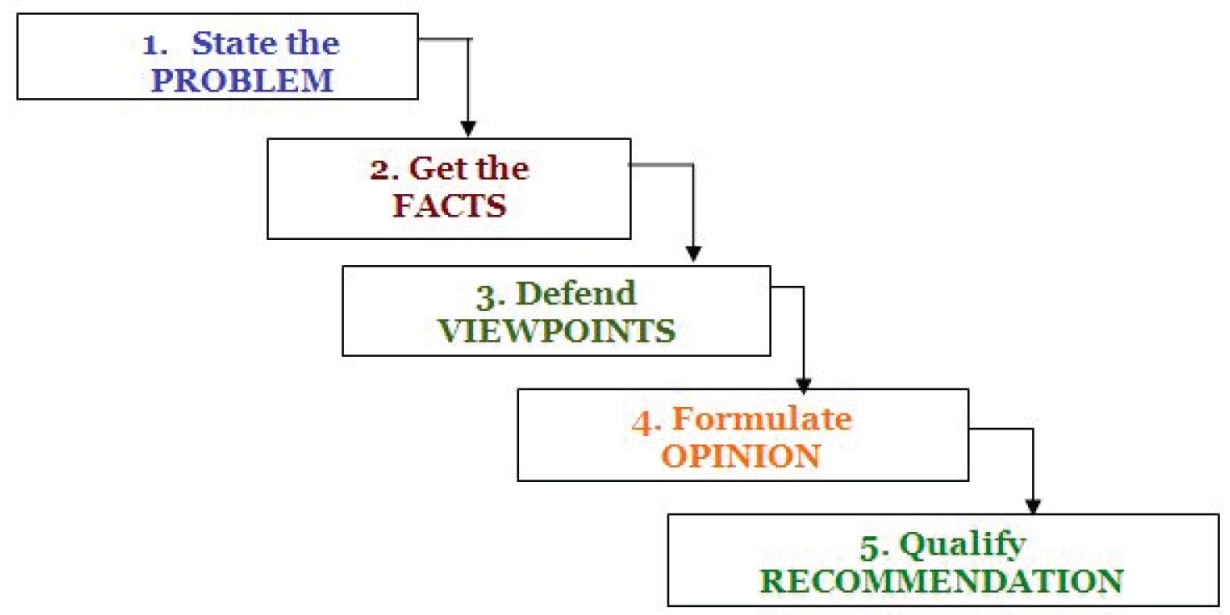

in describing and understanding variability. Variability means that observations of the phenomenon do not yield the same outcomes or results. Statistical tools give engineering managers useful ways to assimilate variability in their processes of decision-making (Hox, Moerbeek, \& Van de Schoot, 2017). Statistics in engineering help engineering managers to have a framework in the description of variability and in learning potential sources of variability. Engineering managers first collect data, whereby the data is always a sample that is selected from the population. The three methods of collecting data in the engineering field are:

a) Retrospective study, whereby historical data is used

b) Observational study

c) Designed experiment

The procedure of an effective data collection simplifies the analysis and leads to an understanding of the process that is being studied (Mertler \& Reinhart, 2016).

\section{Implications to the Project Managers}

Project managers are also involved in the use of statistical tools in managing their projects. Project managers need to collect data and to analyze it as they work on their projects. The data helps the project managers in decision-making just as it helps the engineering managers. Many organizations are faced with risks that are unseen when they want to implement new systems, to sell new products, or to improve an already established product. Thus, the organizations require hiring project managers who are well-acquainted with using statistical tools (Ott \& Longnecker, 2015). The project managers employ the tools that they deem fit for their projects, depending on the projects that they are undertaking. Also, the project managers need finances that will help in carrying out their operations, which force the use of statistical tools to analyze large sums of finances. Sometimes, the project may be about helping a country to settle a certain problem that affects it and its people. To conduct the project, they are duty-bound to collect data and to analyze it perfectly to ensure that they provide the required solutions and will help the country in making decisions. Statistical tools also connect the project managers to the facts about a certain problem, which make them more knowledgeable in their field of work. At the same time, project managers need to use statistical tools when determining the measures of central tendency. 


\section{Applications of Effective and Ineffective Statistical Tools in Project Management Environment to Engineering Managers and Project Managers}

Though these variables, their concepts, and models are vital to projects, engineers and technical professions can be just as important. An engineer was required to use technology and math for solving problems, but as of now, the engineer must use these tools to offer economically viable solutions. Thus, the variables, their concepts, and models also apply to engineering decisions, as it is important to make good decisions throughout the project lifecycle. Engineers must be aware of business management and maturity models to maximize on their technical knowledge for investors.

There are different management schools of thinking, as management concepts and engineering are scientifically based. Engineering relies on the scientific concept of "cause and effect," which links management to engineering. Though research addresses the essential models for identifying project elements, this is only done from a business perspective. Thus, this study takes an engineering perspective and uses pure engineering filed techniques, such as budgeting, equipment, purchasing material, and more. Engineers and project managers can use many decision-making methods for engineering problems and for screening projects for viability.

With scholarly information on these variables, their concepts, and models, this study evaluates how they can affect project management and operational performance to find the best practices. The IE/EM profession and research field heavily relies on project management and operational performance, and lean thinking is not always the answer to problem-solving. As a result, these variables, their concepts, and models help to create different environments in the profession. With this study, industrial engineering and engineering management will also benefit because all organizations need to make new products to succeed. Additionally, stakeholders, such as system engineers, project managers, other experts in industrial engineering and engineering management, can find information on applying maturity to project management. This will encourage them to maximize on the system engineering and project management roles for success.

In the world of engineering, many departments employ the use of statistical analysis tools, specifically almost all operations in engineering depend on statistics. When measuring a physical quantity, many different values can be obtained from observations. From the measurements, the most probable value must be determined. Also, it must be discovered how an observation can vary from the most probable value. From there, the reason why it varies in the way it does can be learned. Statistics give engineers a way of ensuring that they measure this probable value together with ways of dividing the values (variables) into portions that they can allocate to different sources (Ott \& Longnecker, 2015).

In chemical engineering, when large amounts of data are collected, the engineering managers believe that the data holds a lot of information about the company, but they cannot interpret it when it is raw. This brings about the need for the respective engineering managers to apply the use of statistical analysis tools to analyze and simplify the data. This data usually has many parameters that need to be estimated, which requires multiple regressions as the statistical analysis tool. Statistical analysis tools are also useful, as they help in determining the effect of each independent variable in a given study. The most common application of the statistical tools to the processing industries is the statistical techniques in quality control. The engineering managers also apply the statistical tools to come up with a graphical presentation on the rates of production. Graphs are easy to interpret, so the managers can easily make decisions by tracking the trend of production in the company over a given period.

Effective tools are useful to project managers, and statistics are important when it comes to the project planning stage. Handling the organization of both easy and difficult tasks requires a lot of determination, as businesses must generate new products and services regularly to penetrate new markets and increase sales (Modarres, 2016). Organizations must create better methods to increase production and to ensure that the cost of production is reduced. Also, they must generate ways of improving the process of delivering goods and services to the market. Project managers will help 
the organization to achieve these goals by collecting data from daily activities with statistical tools to analyze the data, interpret the data, and then make decisions based on the conclusion drawn from the projects. It is clear that project managers use statistical tools to help them focus on the bigger picture of the organization and to see how the organization is going to improve by implementing some policies from the analyzed data (Velte \& Stawinoga, 2017). Project managers use the statistical tools to ensure the organization avoids making blind decisions that have no base, and they apply effective statistical analysis tools in the risk management process.

In some instances, the project managers seek to analyze if a particular venture is worth taking the risk. If so, then they will advise the other stakeholders accordingly. A good example of such a risk is penetrating new markets, as they will use effective statistical analysis tools to discover if new markets will get more expenses than income or vice versa. Project managers may achieve this objective by finding out factors, such as the potential buyers in the new market, the purchasing power of those potential buyers, and the expense that the organization will incur by taking their products or services to the new markets (Velte \& Stawinoga, 2017). Additionally, project managers use the statistical analysis tools to find out how the quality assurance programs of the organization will be improved. Effective statistical analysis tools provide methods of controlling and measuring the processes of production, reducing the level of waste, and ensuring that the production processes are consistent. Project managers also use effective statistical analysis tools to help them identify healthy relationships that will improve overall performance. Thus, analyzing the data will help in showing how different variables contribute to the performance of the organization.

\section{Lessons Learned to the Engineering Manager and Project Manager}

Both engineering managers and project managers learn several lessons from effective and ineffective statistical analysis tools in a project management environment. First of all, they have learned that there are several ways of handling big data. Big data needs maximum care when being handled because the loss of it can bring many damages (Zikmund, Babin, Carr, \& Griffin, 2013). At the same time, they have learned how to select the most suitable tools, depending on the kinds of answers that they want to draw from specific situations. Additionally, they have learned that the tools could be erroneous and can give out false results, leading to making the wrong decisions. Tools are also helpful to make work easier by analyzing big data, which could cost time and could generate the wrong results.

\section{CONCLUSION}

\section{Recommendations for Future Research}

More advancement needs to be done on the effective and ineffective statistical analysis tools because the statistical analysis tools have proved to be somewhat erroneous. For example, parametric tools are well-known in giving results that are erroneous when one is not careful. Again, some of the analysis tools have very long methods that make it difficult to come up with an answer (Williams, 2018). The tools need some advancements and corrections to ensure that the process is not hard for them to conduct their analysis. It is important to note that before data analysis, one is first required to collect the data from the field. The process of collecting data is long and can be hectic (Zikmund et al., 2013). Thus, engineering managers and project managers need to know the best processes that will lead them to the right data. For example, the retrospective study is a process of data collection that uses the data that has been stored, which is sometimes distorted and unreliable in making right decisions. Standards should be set to ensure that the data stored is safe and secure, free from distortions, and reliable for future use.

In addition, the stored data has a long procedure before being accessed, so it is important to ensure that the data is accessible for engineering managers and project managers to access it easily. For researchers to ensure that the statistical analysis tools are effective, they should study the type of data 
to know the most appropriate tool for analysis (Modarres, 2016). Also, the use of statistical tools can only be applied in a phenomenon that can be expressed in quantitative or numerical terms. Engineering managers and project managers can face challenges on which tools to use, so it is recommended that researchers come up with statistical tools for when quantization is not required. It is also important for researchers to ensure that they get access to the right information or knowledge about statistical tools, as researchers sometimes fail because they do not have enough information (Williams, 2018).

Future research can find how these variables, concepts, and models relate in industries and managerial settings to find their strengths and weaknesses. Also, future research can study them from various perspectives. For example, the organizational, strategic, or cultural point of views can be assessed. Thus, researchers can study how these variables, concepts, models, and their relationship are perceived and affected by culture, strategy, human resources, and operations.

\section{Limitations of the Study}

This study contained some research limitations. First of all, statistical tools do not study the nature of a problem that cannot be expressed in numerical terms, so these problems cannot be part of statistics. Secondly, there was not enough time to conduct the study sufficiently (Zikmund et al., 2013). Statistical tools are scientific and require a lot of time, so time was one of the limitations of the study. Also, the final results of a statistical analysis are not always reliable, so some studies must be conducted before studying this topic. There were also problems in accessing the relevant books that would provide the information required for the study.

Personally, I encountered a limitation of biases, as I had heard that the researches about statistical tools are always complicated. As I began the research, I thought that the research would not be complete, so I would come to some points and believe the biases. I had worked on the biases before starting my research, and I ensured that I confirmed whatever I had heard from the relevant sources (Zikmund et al., 2013). I also failed to get some of the information that I needed for the research. There are several books that I expected to guide me on research about the descriptive analytics, but I did not even find the exact information.

Mainly, there was a small sample size that limited the information to key factors. Bias and validity problems can result from this limitation, as the findings and conclusions could be compromised. A larger sample size would have been preferable. Furthermore, the key factors and their relationship were studied from a project environment, which makes the conclusions and analysis exclusive to project environments. Thus, these results may not apply to supply chain management, operations management, strategic management, other industries, or managerial settings.

\section{General Conclusion}

Overall, statistical tools are helpful in a project management environment. Engineering managers work with project managers to complete their projects because of the application of statistical tools. The descriptive analytics need knowledge and experience because they sometimes give out erroneous results when not carefully calculated. Another issue is the data collection, as researchers collect data to analyze it and generate the right answers for making decisions. Data collection should be conducted in a manner that it will give the right results after the analysis. A mistake in data collection may lead to a wrong selection of the effective and ineffective tools, which may result in poor analysis and unhelpful decisions. Using statistical tools should generate results that will help in solving problems sufficiently. Research shows that the statistical tools have been developed over time, but they still need improvement to ease the analysis of big data. Still, researchers need to come up with statistical tools that can be used by all other researchers, including the researchers who are not good at math. It is also important to note that effective and ineffective analysis tools differ. When it comes to data analysis, the tools need to be selected according to how effective they are. 


\section{REFERENCES}

Ahern, T., Leavy, B., \& Byrne, P. J. (2014). Complex project management as complex problem solving: A distributed knowledge management perspective. International Journal of Project Management, 32(8), 1371-1381. doi:10.1016/j.ijproman.2013.06.007

Ali, Z., \& Bhaskar, S. B. (2016). Retrieved November 4, 2018, from https://www.ncbi.nlm.nih.gov/pmc/articles/ PMC5037948/

Al-Kadeem, R., Backar, S., Eldardiry, M., \& Haddad, H. (2017a). Review on using system dynamics in designing work systems of project organizations: Product development process case study. International Journal of System Dynamics Applications, 6(2), 52-70. doi:10.4018/IJSDA.2017040103

Andersen, E. S. (2014). Value creation using the mission breakdown structure. International Journal of Project Management, 32(5), 885-892. doi:10.1016/j.ijproman.2013.11.003

Arumugam, V. A., Antony, J., \& Linderman, K. (2016). The influence of challenging goals and structured method on six sigma project performance: A mediated moderation analysis. European Journal of Operational Research, 254(1), 202-213. doi:10.1016/j.ejor.2016.03.022

Aslani, A., Akbari, S., \& Tabasi, S. (2018). The robustness of natural gas energy supply: System dynamics modeling. International Journal of System Dynamics Applications, 7(3), 57-71. doi:10.4018/IJSDA.2018070103

Azar, A. T. (2012). System dynamics as a useful technique for complex systems. International Journal of Industrial and Systems Engineering, 10(4), 377-410. doi:10.1504/IJISE.2012.046298

Badi, S. M., \& Pryke, S. (2016). Assessing the impact of risk allocation on sustainable energy innovation (SEI): The case of private finance initiative (PFI) school projects. International Journal of Managing Projects in Business, 9(2), 259-281. doi:10.1108/IJMPB-10-2015-0103

Besner, C., \& Hobbs, B. (2012). The paradox of risk management: A project management practice perspective. International Journal of Managing Projects in Business, 5(2), 230-247. doi:10.1108/17538371211214923

Brown, S. L., \& Eisenhardt, K. M. (1995). Product development: Past research, present findings, and future directions. Academy of Management Review, 20(2), 343-378. doi:10.5465/amr.1995.9507312922

Burnes, B. (2014). Kurt Lewin and the planned approach to change: A re-appraisal. Journal of Management Studies, 41(6), 977-1002. doi:10.1111/j.1467-6486.2004.00463.x

Carley, K. M., \& Prietula, M. J. (2014). The virtual design team: Simulating how organization structure and information processing tools affect team performance. In Computational Organization Theory. Psychology Press.

Christensen, L. B., Johnson, B., Turner, L. A., \& Christensen, L. B. (2011). Research methods, design, and analysis. Academic Press.

Cova, B., \& Salle, R. (2005). Six key points to merge project marketing into project management. International Journal of Project Management, 23(5), 354-359. doi:10.1016/j.ijproman.2005.01.006

David, M. E., David, F. R., \& David, F. R. (2017). The quantitative strategic planning matrix: A new marketing tool. Journal of Strategic Marketing, 25(4), 342-352. doi:10.1080/0965254X.2016.1148763

Detert, J. R., Schroeder, R. G., \& Mauriel, J. J. (2000). A framework for linking culture and improvement initiatives in organizations. Academy of Management Review, 25(4), 850-863. doi:10.5465/amr.2000.3707740

Easton, G. S., \& Rosenzweig, E. D. (2012). The role of experience in six sigma project success: An empirical analysis of improvement projects. Journal of Operations Management, 30(7), 481-493. doi:10.1016/j. jom.2012.08.002

Eskerod, P., \& Blichfeldt, B. S. (2005). Managing team entrees and withdrawals during the project life cycle. International Journal of Project Management, 23(7), 495-503. doi:10.1016/j.ijproman.2004.12.005

Gafi, E. G., \& Javadian, N. (2018). A system dynamics model for studying the policies of improvement of chicken industry supply chain. International Journal of System Dynamics Applications, 7(4), 20-37. doi:10.4018/ IJSDA.2018100102 
Galli, B. (2018a). Application of system engineering to project management-How to view their relationship. International Journal of System Dynamics Applications, 7(4), 76-97. doi:10.4018/IJSDA.2018100105

Galli, B. (2018b). Can project management help improve lean six sigma? IEEE Engineering Management Review, 46(2), 55-64. doi:10.1109/EMR.2018.2810146

Galli, B. (2018c). Risks related to lean six sigma deployment and sustainment risks: How project management can help. International Journal of Service Science, Management, Engineering, and Technology, 9(3), 82-105. doi:10.4018/IJSSMET.2018070106

Galli, B., \& Hernandez-Lopez, P. (2018). Risks management in agile new product development project environments-A review of literature. International Journal of Risk and Contingency Management, 7(4), 37-67. doi:10.4018/IJRCM.2018100103

Galli, B., \& Kaviani, M. A. (2018). The impacts of risk on deploying and sustaining lean six sigma initiatives. International Journal of Risk and Contingency Management, 7(1), 46-70. doi:10.4018/IJRCM.2018010104

Galli, B., Kaviani, M. A., Bottani, E., \& Murino, T. (2017). An investigation of shared leadership \& key performance indicators in six sigma projects. International Journal of Strategic Decision Sciences, 8(4), 1-45. doi:10.4018/IJSDS.2017100101

George, G., Haas, M. R., \& Pentland, A. (2014). Big data and management. Academic Press.

Gholizad, A., Ahmadi, L., Hassannayebi, E., Memarpour, M., \& Shakibayifar, M. (2017). A system dynamics model for the analysis of the deregulation in electricity market. International Journal of System Dynamics Applications, 6(2), 1-30. doi:10.4018/IJSDA.2017040101

Ghosh, K., Ramteke, M., \& Srinivasan, R. (2014). Optimal variable selection for effective statistical process monitoring. Computers \& Chemical Engineering, 60, 260-276. doi:10.1016/j.compchemeng.2013.09.014

Gimenez-Espin, J. A.-J.-C., Jiménez-Jiménez, D., \& Martínez-Costa, M. (2013). Organizational culture for total quality management. Total Quality Management \& Business Excellence, 24(5-6), 678-692. doi:10.1080/ 14783363.2012.707409

Harris, F., \& McCaffer, R. (2013). Modern construction management. John Wiley \& Sons.

Hartono, , \& Wijaya, , \& Arini. (2014). An empirically verified project risk maturity model: Evidence from Indonesian construction industry. International Journal of Managing Projects in Business, 7(2), 263-284. doi:10.1108/IJMPB-03-2013-0015

Hazır, Ö. (2015). A review of analytical models, approaches, and decision support tools in project monitoring and control. International Journal of Project Management, 33(4), 808-815. doi:10.1016/j.ijproman.2014.09.005

Healey, J. F. (2014). Statistics: A tool for social research. Cengage Learning.

Hoon Kwak, Y., \& Dixon, C. K. (2008). Risk management framework for pharmaceutical research and development projects. International Journal of Managing Projects in Business, 1(4), 552-565. doi:10.1108/17538370810906255

Hox, J. J., Moerbeek, M., \& Van de Schoot, R. (2017). Multilevel analysis: Techniques and applications. Routledge. doi:10.4324/9781315650982

Omamo, A. O., Rodriguez, A. J., \& Muliaro, J. W. (2018). A systems dynamics model for mobile industry governance in the context of the Kenyan vision 2030. International Journal of System Dynamics Applications, 7(2), 81-100. doi:10.4018/IJSDA.2018040105

Kerzner, H., \& Kerzner, H. R. (2017). Project management: A systems approach to planning, scheduling, and controlling. John Wiley \& Sons.

Labedz, C. S., \& Gray, J. R. (2013). Accounting for lean implementation in government enterprise: Intended and unintended consequences. International Journal of System Dynamics Applications, 2(1), 14-36. doi:10.4018/ ijsda.2013010102

Lee, J., Lapira, E., Bagheri, B., \& Kao, H. (2013). Recent advances and trends in predictive manufacturing systems in big data environment. Journal of Cleaner Production, 3(10), 45-55. 
Loyd, N. (2016). Implementation of a plan-do-check-act pedagogy in industrial engineering education. International Journal of Engineering Education, 32(3), 1260-1267.

Manly, B. F., \& Alberto, J. A. N. (2016). Multivariate statistical methods: A primer. Chapman and Hall/CRC.

Marcelino-Sádaba, S., Pérez-Ezcurdia, A., Lazcano, A. M. E., \& Villanueva, P. (2014). Project risk management methodology for small firms. International Journal of Project Management, 32(2), 327-340. doi:10.1016/j. ijproman.2013.05.009

Marchewka, J. T. (2014). Information technology project management. John Wiley \& Sons.

Medina, R., \& Medina, A. (2015). The competence loop: Competence management in knowledge-intensive, project-intensive organizations. International Journal of Managing Projects in Business, 8(2), 279-299. doi:10.1108/IJMPB-09-2014-0061

Mertler, C. A., \& Reinhart, R. V. (2016). Advanced and multivariate statistical methods: Practical application and interpretation. Routledge.

Milner, C. D., \& Savage, B. M. (2016). Modeling continuous improvement evolution in the service sector: A comparative case study. International Journal of Quality and Service Sciences, 8(3), 438-460. doi:10.1108/ IJQSS-07-2016-0052

Modarres, M. (2016). Risk analysis in engineering: techniques, tools, and trends. CRC Press. doi:10.1201/b21429

Nabavi, S. H., \& Balochian, S. (2018). The stability of a class of fractional order switching system with time-delay actuator. International Journal of System Dynamics Applications, 7(1), 85-96. doi:10.4018/IJSDA.2018010105

Nagel, R. (2015). Operational optimization: A lean six sigma approach to sustainability. Proceedings of the Water Environment Federation, 3(4), 1-12. doi:10.2175/193864715819556688

Nikabadi, M. S., \& Hakaki, A. (2018). A dynamic model of effective factors on open innovation in manufacturing small and medium sized companies. International Journal of System Dynamics Applications, 7(1), 1-26. doi:10.4018/IJSDA.2018010101

Ott, R. L., \& Longnecker, M. T. (2015). An introduction to statistical methods and data analysis. Nelson Education.

Papke-Shields, K. E., \& Boyer-Wright, K. M. (2017). Strategic planning characteristics applied to project management. International Journal of Project Management, 35(2), 169-179. doi:10.1016/j.jproman.2016.10.015

Parast, M. M. (2011). The effect of six sigma projects on innovation and firm performance. International Journal of Project Management, 29(1), 45-55. doi:10.1016/j.ijproman.2010.01.006

Parker, D. W., Parsons, N., \& Isharyanto, F. (2015). The inclusion of strategic management theories to project management. International Journal of Managing Projects in Business, 8(3), 552-573. doi:10.1108/ IJMPB-11-2014-0079

Schwedes, O., Riedel, V., \& Dziekan, K. (2017). Project planning vs. strategic planning: Promoting a different perspective for sustainable transport policy in European R\&D projects. Case Studies on Transport Policy, 5(1), 31-37. doi:10.1016/j.cstp.2016.08.006

Sharon, A., Weck, O. L., \& Dori, D. (2013). Improving project-product lifecycle management with model-based design structure matrix: A joint project management and systems engineering approach. Systems Engineering, 16(4), 413-426. doi:10.1002/sys.21240

Shenhar, A. J., \& Levy, O. (2007). Mapping the dimensions of project success. Project Management Journal, $28,5-13$.

Simundic, A. (2018). Practical recommendations for statistical analysis and data presentation. Biochemia Medica Journal. Retrieved November 4, 2018, from https://www.biochemia-medica.com/en/journal/22/1/10.11613/ BM.2012.003

Sutherland, S. (2004). Creating a culture of data use for continuous improvement: A case study of an Edison project school. The American Journal of Evaluation, 25(3), 277-293. doi:10.1177/109821400402500302 
Svejvig, P., \& Andersen, P. (2015). Rethinking project management: A structured literature review with a critical look at the brave new world. International Journal of Project Management, 33(2), 278-290. doi:10.1016/j. ijproman.2014.06.004

Todorović, M. L., Petrović, D. Č., Mihić, M. M., Obradović, V. L., \& Bushuyev, S. D. (2015). Project success analysis framework: A knowledge-based approach in project management. International Journal of Project Management, 33(4), 772-783. doi:10.1016/j.ijproman.2014.10.009

Usman Tariq, M. (2013). A six sigma based risk management framework for handling undesired effects associated with delays in project completion. International Journal of Lean Six Sigma, 4(3), 265-279. doi:10.1108/ IJLSS-05-2013-0028

Velte, P., \& Stawinoga, M. (2017). Integrated reporting: The current state of empirical research, limitations and future research implications. Journal of Management Control, 28(3), 275-320. doi:10.1007/s00187-016-0235-4

Vergura, S., Acciani, G., Amoruso, V., Patrono, G. E., \& Vacca, F. (2009). Descriptive and inferential statistics for supervising and monitoring the operation of PV plants. IEEE Transactions on Industrial Electronics, 56(11), 4456-4464. doi:10.1109/TIE.2008.927404

Von Thiele Schwarz, U. N.-H., Nielsen, K. M., Stenfors-Hayes, T., \& Hasson, H. (2017). Using kaizen to improve employee well-being: Results from two organizational intervention studies. Human Relations, 70(8), $966-993$. doi:10.1177/0018726716677071 PMID:28736455

Williams, J. T. (2018). The importance of statistics in management decision-making. Retrieved November 4, 2018, from https://smallbusiness.chron.com/importance-statistics-management-decisionmaking-4589.html

Winter, M., Andersen, E. S., Elvin, R., \& Levene, R. (2006a). Focusing on business projects as an area for future research: An exploratory discussion of four different perspectives. International Journal of Project Management, 24(8), 699-709. doi:10.1016/j.ijproman.2006.08.005

Xiong, W., Zhao, X., Yuan, J.-F., \& Luo, S. (2017). Ex post risk management in public-private partnership infrastructure projects. Project Management Journal, 48(3), 76-89. doi:10.1177/875697281704800305

Xue, R., Baron, C., \& Esteban, P. (2016). Improving cooperation between systems engineers and project managers in engineering projects-towards the alignment of systems engineering and project management standards and guides. Proceedings of Joint Conference on Mechanical, Design Engineering \& Advanced Manufacturing, 24(2), 23-40.

Xue, R., Baron, C., \& Esteban, P. (2017). Optimizing product development in industry by alignment of the ISO/ IEC 15288 systems engineering standard and the PMBoK guide. International Journal of Product Development, 22(1), 65-80. doi:10.1504/IJPD.2017.085278

Yun, S., Choi, J., Oliveira, D. P., Mulva, S. P., \& Kang, Y. (2016). Measuring project management inputs throughout capital project delivery. International Journal of Project Management, 34(7), 1167-1182. doi:10.1016/j.ijproman.2016.06.004

Zelinka, D., \& Amadei, B. (2019). Systems approach for modeling interactions among the sustainable development goals part 1: Cross-impact network analysis. International Journal of System Dynamics Applications, 8(1), 23-40. doi:10.4018/IJSDA.2019010102

Zhang, X., Bao, H., Wang, H., \& Skitmore, M. (2016). A model for determining the optimal project life span and concession period of BOT projects. International Journal of Project Management, 34(3), 523-532. doi:10.1016/j. ijproman.2016.01.005

Zikmund, W. G., Babin, B. J., Carr, J. C., \& Griffin, M. (2013). Business research methods. Cengage Learning.

Zwikael, O., \& Smyrk, J. (2012). A general framework for gauging the performance of initiatives to enhance organizational value. British Journal of Management, 23, S6-S22. doi:10.1111/j.1467-8551.2012.00823.x 
Brian J. Galli $(P h D)$ works as an Assistant Professor of Industrial Engineering \& Engineering Management in the Fred DeMatteis School of Engineering \& Applied Science at Hofstra University. He also currently serves as the Graduate Director for the Engineering Management Master degree program in the school. He has previously served as faculty at other academic institutions, including: Long Island University, New York Institute of Technology (NYIT), American Public University (APUS), SUNY Binghamton, and SUNY Stony Brook. Prior to joining academia, he worked in industry for over 12 years in which he applied industrial engineering, project management and continuous improvement in a wide variety of arenas, including healthcare, manufacturing, transactional, and service environments. He also provides project management support and training in the areas of process improvement, project management, and analytics. 